\title{
Production and quality of watermelon fruits under salinity management strategies and nitrogen fertilization
}

\section{Produção e qualidade de frutos de melancieira sob estratégias de manejo de salinidade e nitrogênio}

\author{
Saulo Soares da Silva ${ }^{1}$; Geovani Soares de Lima ${ }^{2 *}$; Vera Lúcia Antunes de Lima ${ }^{3}$; \\ Hans Raj Gheyi ${ }^{3}$; Lauriane Almeida dos Anjos Soares ${ }^{4}$; Janine Patrícia Melo \\ Oliveira $^{5}$; Auryclennedy Calou de Araújo ${ }^{1}$; Josivanda Palmeira Gomes ${ }^{3}$
}

\section{Highlights:}

Salt stress at the vegetative and flowering stages reduces the contents of ascorbic acid and soluble solids. Production is drastically affected by salinity at the vegetative and flowering stages.

The $50 \mathrm{mg}$ of $\mathrm{N} \mathrm{kg}^{-1}$ of soil promotes higher production of watermelon and anthocyanins.

\begin{abstract}
The objective of this study was to evaluate the production and quality of 'Sugar Baby' watermelon fruits under different strategies of irrigation with saline water and nitrogen $(\mathrm{N})$ fertilization in an experiment conducted in a protected environment in Campina Grande, Paraíba, Brazil. The experimental design adopted was in blocks with a $6 \times 2$ factorial scheme, corresponding to six strategies of irrigation with saline water applied at different phenological stages of the crop (SE irrigation with low-salinity water throughout the cycle; salt stress at the vegetative stage VE; vegetative and flowering VE/FL; flowering FL; fruiting FR; fruit maturation MAT) and two N doses (50 and $100 \%$ of the recommendation, equivalent to 50 and $100 \mathrm{mg}$ of $\mathrm{N} \mathrm{kg}^{-1}$ of soil) with five replicates. Two levels of irrigation water salinity were studied, one with low and the other with high electrical conductivity ( $\mathrm{ECW}=0.8$ and 3.2 $\mathrm{dS} \mathrm{m}^{-1}$ ). The salt stress applied at the vegetative and flowering stages reduced the contents of ascorbic acid and total soluble solids in 'Sugar Baby' watermelon fruits. The dose equivalent to $50 \%$ of the $\mathrm{N}$ recommendation promoted a greater fresh weight of watermelon fruits. Fertilization with $100 \%$ of $\mathrm{N}$ increased the hydrogen potential of watermelon fruits under salt stress at the vegetative and flowering stages. The anthocyanin content of watermelon fruits decreased under salt stress, regardless of the development stage; however, with $50 \%$ of recommendation of $\mathrm{N}$, there was an increase in this variable. Key words: Nitrogen fertilization. Citrullus lanatus. Salt stress.
\end{abstract}

1 Discentes do Curso de Doutorado do Programa de Pós-Graduação em Engenharia Agrícola, Universidade Federal de Campina Grande, UFCG, Centro de Tecnologia e Recursos Naturais, Campina Grande, PB, Brasil. E-mail: saulosoares90@gmail.com; auryclennedy@hotmail.com

2 Prof. Visitante, Unidade Acadêmica de Ciências Agrárias, UFCG, Pombal, PB, Brasil. E-mail: geovani.soares@pq.cnpq.br

3 Profs., Centro de Tecnologia e Recursos Naturais, UFCG, Campina Grande, PB, Brasil. E-mail: antuneslima@gmail.com; hans@ pq.cnpq.br; josivanda@gmail.com

4 Profa, Unidade Acadêmica de Ciências Agrárias, UFCG, Pombal, PB, Brasil. E-mail: lauriane.soares@pq.cnpq.br

5 M.e, Programa de Pós-Graduação em Sistemas Agroindustriais, UFCG, Pombal, PB, Brasil. E-mail: janineeng.alimentos@ gmail.com

* Author for correspondence 


\section{Resumo}

Objetivou-se com este trabalho avaliar a produção e a qualidade de frutos de melancieira 'Sugar Baby' sob diferentes estratégias de irrigação com águas salinas e adubação nitrogenada, em experimento conduzido em ambiente protegido em Campina Grande, Paraíba, PB. Adotou-se o delineamento experimental em blocos casualizados, arranjados em esquema fatorial $6 \times 2$, sendo seis estratégias de irrigação com águas salinas aplicadas nos estádios fenológicos da cultura ( irrigação com água de baixa salinidade durante todo o ciclo - SE; estresse salino na fase vegetativa - VE; vegetativa e na floração - VE/FL; -floração - FL; - frutificação - FR; maturação dos frutos - MAT) e duas doses de nitrogênio

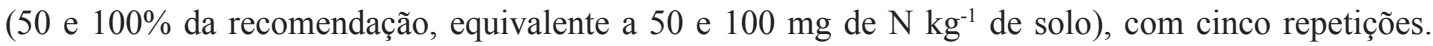
Foram estudados dois níveis de salinidade da água de irrigação, um com baixa e outro com alto nível de condutividade elétrica da água de irrigação $\left(\mathrm{CEa}=0,8 \mathrm{e} 3,2 \mathrm{dS} \mathrm{m}^{-1}\right)$. O estresse salino aplicado nas fases vegetativa e de floração reduziu o teor de ácido ascórbico e de sólidos solúveis totais nos frutos da melancieira 'Sugar Baby'. A dose de 50\% da recomendação de N proporciona maior massa fresca dos frutos da melancieira. Adubação com $100 \%$ de N proporcionou incremento no potencial hidrogeniônico dos frutos de melancieira sob estresse salino nas fases vegetativa e de floração. $\mathrm{O}$ teor de antocianinas dos frutos de melancieira reduziu com o estresse salino, independente da fase de desenvolvimento; contudo, com $50 \%$ da recomendação de $\mathrm{N}$ houve aumento nesta variável.

Palavras-chave: Adubação nitrogenada. Citrullus lanatus. Estresse salino.

\section{Introduction}

Watermelon is an herbaceous plant belonging to the Cucurbitaceae family that is cultivated and consumed all over the world. It is a vegetable cultivated in Brazil, mainly in its Northeast region, because of the favorable soil and climatic conditions to its cultivation, and it can be cultivated yearround under irrigated conditions (Lopes, Rocha, Gonçalves, Cunha, \& Silva, 2016). According to the Instituto Brasileiro de Geografia e Estatística (2017), 2,090,432 tons of watermelon were produced in 90,447 hectares in Brazil in 2016, with the Northeast region accounting for $32 \%$ of the national production.

Limitations regarding water availability commonly occur in this region, due to the predominance of irregular rainfall associated with high temperatures and evaporation rates, requiring the use of irrigation to ensure crop production (Souza, Nobre, Silva, Sousa, \& Silva, 2015). However, the water sources available in this region usually have high salt contents that can hamper agricultural production, due to the osmotic and/or ionic effects on plants (Melo et al., 2018).
The use of waters with excess salts can compromise the physiological and biochemical functions of plants, causing disturbances in their water relations, changes in the absorption and use of nutrients, besides the accumulation of toxic ions (Torres et al., 2014), which can cause reductions in plant growth and production, consequently leading to decrease in fruit postharvest quality. Due to water scarcity and the predominance of waters with high salt concentrations, the use of saline water becomes a challenge for irrigated agriculture. Thus, it is necessary to adopt water salinity management strategies to ensure sustainability in the agricultural production (Fageria, Gheyi, \& Moreira, 2011; Guedes et al., 2015), as these strategies can reduce the concentration and entry of salts in the root zone (Lacerda et al., 2011) and consequently their negative effects on plants.

Among the strategies for water salinity management, the application of saline water at different phenological stages of plants, in which the crop has a higher tolerance to salt stress, stands out because the sensitivity and tolerance of crops to the effects of salinity may vary between plant 
development stages, fertilization, and irrigation management practices, and edaphoclimatic conditions, among others (Lacerda et al., 2009; Barbosa et al., 2012). Another alternative that can minimize the deleterious effects of salt stress on plants is nitrogen $(\mathrm{N})$ fertilization. This can be explained by the functions performed by this macronutrient that participates in several organic compounds, such as nucleic acids, chlorophyll, proteins, and amino acids (Taiz, Zeiger, Møller, \& Murphy, 2017). Through their synthesis, organic compounds can increase plant tolerance to salinity, because they increase the osmotic adjustment capacity (Gupta \& Huang, 2014). In addition, N is related to plant defense and the most important biochemical and physiological processes that occur, such as photosynthesis and respiration (Barros, Araújo, Neves, Campos, \& Tosin, 2012).
In this context, the objective of this study was to evaluate the production and postharvest quality of fruits of 'Sugar Baby' watermelon under water salinity management strategies and $\mathrm{N}$ fertilization in a protected environment.

\section{Material and Methods}

The experiment was carried out from May to August 2017, under greenhouse conditions (arched roof covered with 150-micron transparent lowdensity polyethylene plastic, to allow the passage of light), at the Federal University of Campina Grande, in Campina Grande, State of Paraíba, Brazil ( $7^{\circ} 15^{\prime}$ 18 " S, 35 $52^{\circ}$ ' 18 " W and an average altitude of 550 $\mathrm{m})$. The data of temperature during the experimental period are shown in Figure 1.

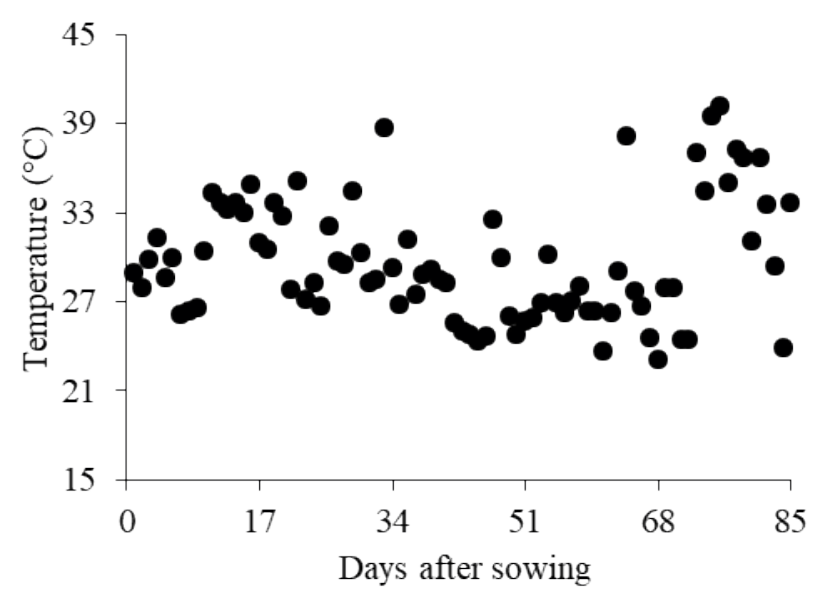

Figure 1. Mean values of temperature, obtained along the experimental period.

The experimental design was in randomized blocks, in a $6 \times 2$ factorial scheme six strategies of salinity management; two $\mathrm{N}$ doses: $50 \%$ and $100 \%$ of the recommendation of Novais, Neves and Barros (1991) [equivalent to 50 and $100 \mathrm{mg}$ of $\mathrm{N} \mathrm{kg}^{-1}$ of soil; in the form of urea $(45 \%$ of $\mathrm{N})]\}$; with five replicates, totaling 60 experimental units. Nitrogen doses were supplied in three equal top-dressing applications at 25,37 , and 47 days after sowing (DAS). The six water salinity management strategies consisted of two levels of electrical conductivity (ECw), one of low salinity $\left(\mathrm{ECw}=0.8 \mathrm{dS} \mathrm{m}^{-1}\right)$ and the other of high salinity $\left(\mathrm{ECW}=3.2 \mathrm{dS} \mathrm{m}^{-1}\right)$, varying according to the phenological stages of the plants: vegetative the period between the appearance of the second true leaf until the emergence of the first female flower (25-41 DAS), flowering from the first female flower to fruit setting (42-55 DAS), fruiting from fruit 
setting to fruit filling (56-66 DAS), and maturation from fruit filling to harvest (67-85 DAS). The ECw level of $3.2 \mathrm{dS} \mathrm{m}^{-1}$ was established considering that the watermelon crop as moderately sensitive to salt stress (Ayers \& Westcot, 1999), and the water threshold salinity was $3.0 \mathrm{dS} \mathrm{m}^{-1}$.

The crop used was the watermelon, 'Sugar Baby', which stands out for its early cycle, with harvest carried out from 75 days after planting. It is a rustic plant, with vigorous foliage and is tolerant of high temperatures. It produces round fruits, with a dark green rind, weighing around 2 to $4 \mathrm{~kg}$. These fruits have pulp with high sugar content that is soft and has an intense red color.

The plants were grown in plastic containers adapted as drainage lysimeters with 20 L capacity, which received at the base a 3-cm-thick layer of crushed stone and a geotextile to avoid clogging of the drainage system by soil material. After covering the base of the container, a 4-mmdiameter transparent tube was connected to its base, to facilitate drainage, and connected to a plastic container for collecting the drained water, to function as a drainage lysimeter. Then, each container was filled with $24 \mathrm{~kg}$ of an Entisol with sandy loam texture from cultivated areas of the municipality of Lagoa Seca, PB, whose physical and chemical attributes were determined according to Donagema, Campos, Calderano, Teixeira and Viana (2011): $\mathrm{Ca}^{2+} 2.60 \mathrm{cmol}_{\mathrm{c}} \mathrm{kg}^{-1}, \mathrm{Mg}^{2+} 3.66 \mathrm{cmol}_{\mathrm{c}}$ $\mathrm{kg}^{-1}, \mathrm{Na}^{+} 0.16 \mathrm{cmol}_{\mathrm{c}} \mathrm{kg}^{-1}, \mathrm{~K}^{+} 0.22 \mathrm{cmol}_{\mathrm{c}} \mathrm{kg}^{-1}, \mathrm{H}^{+}+\mathrm{Al}^{3+}$ $1.93 \mathrm{cmol}_{\mathrm{c}} \mathrm{kg}^{-1}$, CEC $8.57 \mathrm{cmol}_{\mathrm{c}} \mathrm{kg}^{-1}$, organic matter 1.36 dag kg-1 $^{-1}, \mathrm{P} 6.8 \mathrm{mg} \mathrm{kg}^{-1}, \mathrm{pH}$ in water (1:2.5)5.90 electrical conductivity of soil saturation extract 0.19 $\mathrm{dS} \mathrm{m}^{-1}$, sand $732.9 \mathrm{~g} \mathrm{~kg}^{-1}$, silt $142.1 \mathrm{~g} \mathrm{~kg}^{-1}$, clay125 $\mathrm{g}$ $\mathrm{kg}^{-1}$, water retention at 33.42 and $1519.5 \mathrm{kPa} 11.98$ dag $\mathrm{kg}^{-1}$, and $4.32 \mathrm{dag}^{\mathrm{kg}}{ }^{-1}$.

Phosphorus and potassium fertilization were performed as recommended by Novais et al. (1991), by applying 300 and $150 \mathrm{mg} \mathrm{kg}^{-1}$ of soil $\mathrm{P}_{2} \mathrm{O}_{5}$ and $\mathrm{K}_{2} \mathrm{O}$, respectively, in the forms of single superphosphate and potassium nitrate. The recommended amounts of $\mathrm{K}_{2} \mathrm{O}$ and $\mathrm{P}_{2} \mathrm{O}_{5}$ were applied as top-dressing, split by three equal applications at 22, 40, and 45 DAS for $\mathrm{K}$, while $\mathrm{P}$ was applied at 16, 32, and 43 DAS.

The water of low salinity level $\left(0.8 \mathrm{dS} \mathrm{m}^{-1}\right)$ was obtained by diluting the public-supply water $(\mathrm{ECW}$ $\left.=1.80 \mathrm{dS} \mathrm{m}^{-1}\right)$ with rainwater $\left(\mathrm{ECw}=0.02 \mathrm{dS} \mathrm{m}^{-1}\right)$; the level corresponding to the ECW of $3.2 \mathrm{dS} \mathrm{m}^{-1}$ was prepared by adding salts in the form of chloride, to obtain a 7:2:1 ratio of $\mathrm{Na}: \mathrm{Ca}: \mathrm{Mg}$, respectively, a ratio that prevails in sources of water used for irrigation on small farms in Northeastern Brazil. Irrigation water was prepared considering the relationship between $\mathrm{ECw}$ and salt concentration, according to Richards (1954), as shown in Eq. 1:

$\mathrm{Q}\left(\mathrm{mmolc} \mathrm{L}^{-1}\right)=10 \times \mathrm{ECw}\left(\mathrm{dS} \mathrm{m}^{-1}\right)$

Where:

$\mathrm{Q}=$ Quantity of salts to be applied $\left(\mathrm{mmol}_{\mathrm{c}} \mathrm{L}^{-1}\right)$;

$\mathrm{ECw}=$ Electrical conductivity of water $\left(\mathrm{dS} \mathrm{m}^{-1}\right)$.

At each irrigation event, the ECw levels were checked with a conductivity meter (reading adjusted to the temperature of $25^{\circ} \mathrm{C}$ ). After preparation, the water was stored in a 200-L plastic container, one for each ECw level studied, properly protected to avoid evaporation, entry of rainwater, and contamination with materials that may compromise its quality.

Sowing was performed with four seeds in each lysimeter planted at $3 \mathrm{~cm}$ depth and distributed equidistantly. Before sowing, the soil water content was raised to the level corresponding to field capacity, using low-salinity water $\left(0.8 \mathrm{dS} \mathrm{m}^{-1}\right)$. After sowing, irrigations were carried out daily at 5:00 p.m., applying in each container the volume corresponding to that obtained by the water balance, and the volume of water to be applied to the plants was determined by Eq. 2:

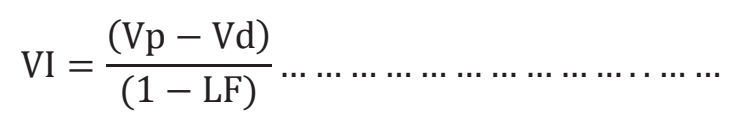

Where:

$\mathrm{VI}=$ Volume of water to be used in the irrigation event $(\mathrm{mL}) ; \mathrm{Va}=$ volume applied in the previous irrigation event $(\mathrm{mL}) ; \mathrm{Vd}=$ Volume drained $(\mathrm{mL})$; and $\mathrm{LF}=$ leaching fraction of 0.20 . 
Plants were vertically trained, leaving only the main branch and three lateral branches per plant. Pollination was performed artificially, and, after fertilization of the flowers, thinning was carried out, leaving only one fruit per plant.

At harvest (85 DAS), the following production variables were analyzed: fruit fresh weight (FFW), determined on a scale with an accuracy of 0.01 $\mathrm{g}$; rind thickness (RT), and pulp thickness (PT) measured with a digital caliper $(\mathrm{mm})$. Postharvest quality of watermelon fruits was determined based on the hydrogen potential $(\mathrm{pH})$, total soluble solids (TSS), anthocyanins (ANT), and ascorbic acid (AA), according to methodologies of the Adolfo Lutz Institute [IAL] (2008), except for anthocyanins, which were determined according to Francis (1982).

The $\mathrm{pH}$ was checked with a digital $\mathrm{pH}$ meter. Samples of watermelon fruits were placed in a 100 $\mathrm{mL}$ beaker, and then the hydrogen potential was checked with buffer solutions. After that, readings were performed in the samples, waiting until stabilization, and the value obtained was recorded. TSS content of the fruit samples was determined with an Abbe refractometer with a scale from $0^{\circ}$ to $92{ }^{\circ}$ Brix.

The AA content was determined by titration, by weighing $0.1 \mathrm{~g}$ of the watermelon sample in an Erlenmeyer flask, which then received $50 \mathrm{~mL}$ of the oxalic acid solution for dilution. The results were expressed in $\mathrm{mg}$ of ascorbic acid per $100 \mathrm{~g}$ of sample and were obtained through Eq. 3.

$\mathrm{mg}$ of ascorbic acid $100 \mathrm{~g}^{-1}$ sample $=\frac{\mathrm{V} \times \mathrm{F} \times 100}{\mathrm{Ws}}$

Where:

$\mathrm{V}=$ spent volume of 2-6-dichlorophenolindophenol (DCPIP) used to titrate the sample

$\mathrm{F}=$ solution factor

$\mathrm{Ws}=$ Sample weight $(\mathrm{g})$
For quantifying the levels of anthocyanins (ANT), anthocyanins were extracted by maceration in mortar and pistil with an ethanol-HCl solution and quantified in UV-Vis spectrophotometer with a wavelength of $535 \mathrm{~nm}$, at which anthocyanins have maximum biological activity. The blank sample consisted only of the ethanol-HCl solution $(1.5 \mathrm{~N})$. The results were expressed in mg of anthocyanins per $100 \mathrm{~g}$ of sample and were obtained through Eq. 4 and 5.

$$
\begin{aligned}
& \mathrm{A}=\left\lfloor\frac{(A B S * D F)}{98.2}\right\rfloor * 100 \\
& \mathrm{DF}=\frac{\text { Final Volume }}{\text { Mass of sample }}
\end{aligned}
$$

Where:

$\mathrm{A}=$ Anthocyanins (mg of anthocyanins $100 \mathrm{~g}^{-1}$ of sample);

$\mathrm{DF}=$ Dilution factor;

ABS $=$ Absorbance of the sample after reading in the spectrophotometer.

The data obtained were evaluated using analysis of variance by $F$ test. In cases of significance, the means were compared by the Tukey test $(p<0.05)$ for salinity management strategies and $\mathrm{N}$ doses using the software program Sisvar (Ferreira, 2014).

\section{Results and Discussion}

There was a significant effect of the water salinity management strategies on pulp thickness and the contents of ascorbic acid, anthocyanins, and total soluble solids in watermelon fruits (Table 1). Nitrogen doses significantly influenced fruit fresh weight and anthocyanin contents. Regarding the interaction between factors (SMS $\times \mathrm{ND}$ ), there was a significant effect on rind thickness, pulp thickness, anthocyanins, and $\mathrm{pH}$ of the fruits of the 'Sugar Baby' watermelon at 85 DAS. 
Table 1

Summary of analysis of variance for fruit fresh weight (FFW - g plant ${ }^{-1}$ ), rind thickness (RT - mm), pulp thickness (PT - mm), hydrogen potential (pH), ascorbic acid (AA - mg 100 $\mathrm{g}^{-1}$ ), anthocyanins (ANT - mg 100g-1), and total soluble solids (TSS - 'Brix) of 'Sugar Baby' watermelon cultivated under water salinity management strategies (SMS) and nitrogen doses (ND) at 85 days after sowing

\begin{tabular}{|c|c|c|c|c|c|c|c|c|}
\hline \multirow{2}{*}{ SV } & \multirow{2}{*}{$\mathrm{DF}$} & \multicolumn{7}{|c|}{ Mean squares } \\
\hline & & FFW & RT & PT & $\mathrm{pH}$ & AA & ANT & TSS \\
\hline SMS & 5 & $81306.7^{\text {ns }}$ & $18.4^{\mathrm{ns}}$ & $2389.9^{* *}$ & $0.02^{\mathrm{ns}}$ & $0.34^{* *}$ & $0.38^{* *}$ & $6.65^{* *}$ \\
\hline ND & 1 & $399105.7^{*}$ & $1.95^{\mathrm{ns}}$ & $822.9^{\text {ns }}$ & $0.04^{\text {ns }}$ & $0.25^{\mathrm{ns}}$ & $0.04^{* *}$ & $0.80^{\text {ns }}$ \\
\hline Interaction (SMS x ND) & 5 & $53156.7^{\mathrm{ns}}$ & $34.0^{* *}$ & $2536.1^{* *}$ & $0.05^{*}$ & $0.13^{\text {ns }}$ & $0.02^{* *}$ & $1.08^{\text {ns }}$ \\
\hline Blocks & 4 & $62744.5^{\mathrm{ns}}$ & $13.5^{\mathrm{ns}}$ & $1434.3^{\text {ns }}$ & $0.02^{\text {ns }}$ & $0.02^{\text {ns }}$ & $0.002^{\mathrm{ns}}$ & $2.87^{\text {ns }}$ \\
\hline Residual & 44 & 49498.2 & 9.4 & 562.5 & 0.01 & 0.07 & 0.002 & 0.93 \\
\hline $\mathrm{CV}(\%)$ & & 22.8 & 37.7 & 21.8 & 2.44 & 9.2 & 11.47 & 11.87 \\
\hline Mean & & 974.3 & 8.1 & 108.4 & 5.50 & 3.04 & 0.40 & 8.13 \\
\hline
\end{tabular}

SV source of variation; DF degree of freedom; CV (\%) coefficient of variation; "significant at 0.05 probability level;

${ }^{* *}$ significant at 0.01 probability level; ${ }^{\text {ns }}$ not significant.

The fresh weight of watermelon fruits was significantly influenced by the $\mathrm{N}$ doses (Figure 2 ), and plants fertilized with $50 \%$ of the $\mathrm{N}$ recommendation obtained the highest FFW (1055.9 $\mathrm{g}$ plant $^{-1}$ ), statistically differing from those fertilized with $100 \%$ of N. There was an increase of $163.10 \mathrm{~g}$ plant $^{-1}(15.44 \%)$ in the FFW between watermelon plants fertilized with $50 \%$ of $\mathrm{N}$ and those that received $100 \%$ of the recommendation. Excess $\mathrm{N}$ can cause an increase in $\mathrm{O}_{2}$ and $\mathrm{H}_{2} \mathrm{O}_{2}$ contents, inducing oxidative stress (Wang, Zhang, Wang, Li, $\& \mathrm{Lu}, 2010)$, reduce photosynthetic rate, stomatal conductance and transpiration ( $\mathrm{Su}$ et al., 2012; Borgognone et al., 2013), and result in a decrease in plant growth (Wong, 2005), which consequently leads to the formation of fruits with a lower weight. V. F. Sousa, Coelho, Souza and Holanda (2005), when evaluating the effects of $\mathrm{N}$ and $\mathrm{K}$ doses on a melon crop, also observed a reduction in marketable yield as the $\mathrm{N}$ doses increased. According to these authors, the reduction of marketable yield with the application of $\mathrm{N}$ doses may be related to the effect of excess $\mathrm{N}$ on plant metabolism.

In the follow up of the interaction between factors $(\mathrm{SMS} \times \mathrm{ND})$ for RT (Figure 3A) and PT (Figure 3B) of watermelon fruits, there was no significant effect when the plants were subjected to irrigation with saline water at the vegetative/flowering stages compared to those under the SMS at the SE, VE, VE/FL, FR and MAT stages and fertilization with $50 \%$ of $\mathrm{N}$. Watermelon plants under fertilization with $100 \%$ of $\mathrm{N}$ obtained the lowest RT and PT when subjected to saline water application at the vegetative/flowering stages compared to those under the SE, VE, and MAT strategies. However, there was no significant difference for RT between plants cultivated under the VE/FL, FL, and FR strategies. 


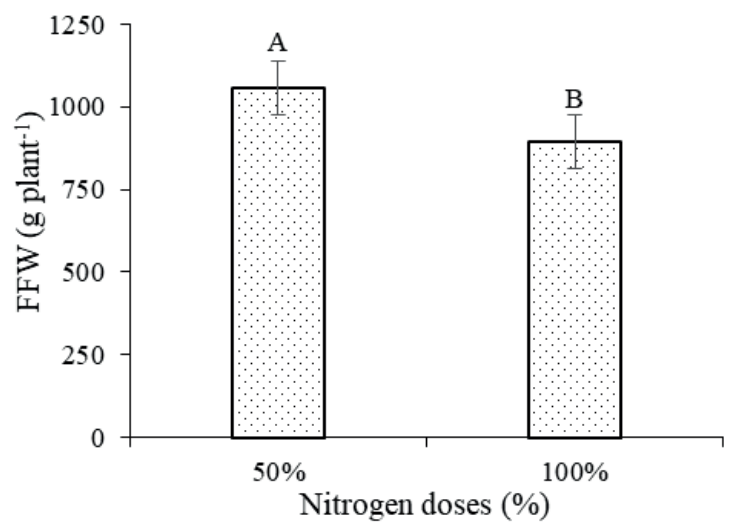

Figure 2. Fruit fresh weight FFW of 'Sugar Baby' watermelon under different strategies of use of saline water as a function of nitrogen doses, at 85 days after sowing.

Vertical bars represent the standard error of the mean $(n=5)$. Means with different letters indicate that the treatments differ from each other by the Tukey test $(\mathrm{p}<0.05)$.

The reductions in RT and PT for fruits of watermelon plants cultivated under the VE/FL strategy can be attributed to their long duration of exposure to salt stress. According to Silva (2016), the long-term exposure of a plant to salt stress can result in water deficit, due to the reduction in the osmotic potential of the soil solution, resulting in physiological changes, affecting growth and production. The energy expenditure to maintain metabolic activities contributes to the formation of fruits with reduced sizes and, consequently, the physical characteristics, RT, and PT were also affected by the stress caused by excess salts.
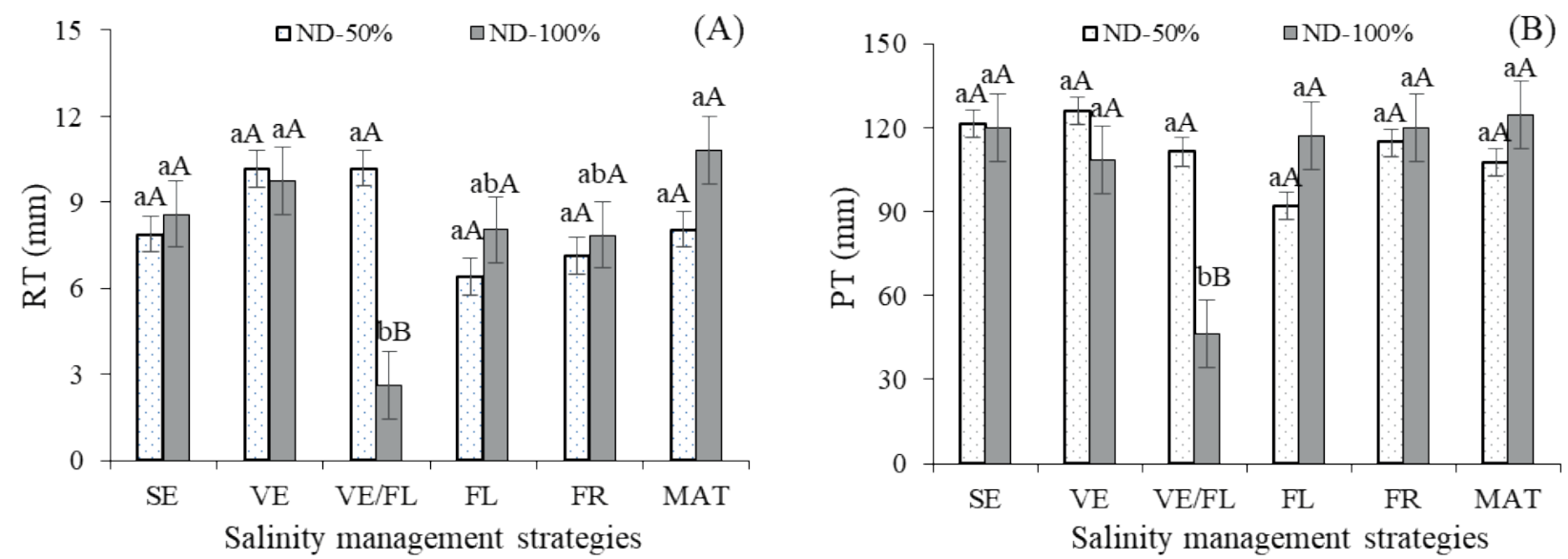

Figure 3. Follow up of the interaction between water salinity management strategies and nitrogen doses for rind thickness RT (A) and pulp thickness PT (B) of "Sugar Baby" watermelon fruits, at 85 days after sowing.

SE no stress throughout the crop cycle; VE salt stress only at the vegetative stage; VE/FL salt stress at the vegetative and flowering stages; FL salt stress at the flowering stage; FR salt stress at the fruiting stage; MAT salt stress at the fruit maturation stage.

Vertical bars represent the standard error of the mean $(n=5)$. Same lowercase and uppercase letters indicate no significant difference between management strategies (Tukey, $\mathrm{p}<0.05$ ) and nitrogen doses (Tukey, $\mathrm{p}<0.05$ ), respectively. 
In the follow up of $\mathrm{N}$ doses within the salinity management strategies for RT (Figure 3A) and PT (Figure 3B) of watermelon fruits, a significant difference was observed only in plants grown under the VE/FL strategy, with $\mathrm{N}$ dose of $50 \%$ promoting the highest values for RT and PT (10.19 and 111.3 $\mathrm{mm}$, respectively) compared to those fertilized with $100 \%$ of the $\mathrm{N}$ recommendation. Reductions of RT and PT in plants grown under $100 \%$ of N can be attributed to changes in metabolism due to $\mathrm{pH}$ variation in the rhizosphere, alkalizing it when absorbed in the form of $\mathrm{NO}_{3}^{-}$or acidifying it when absorbed in the form of $\mathrm{NH}_{4}^{+}$(Oliveira, Korndorfer, \& Pereira, 2007), and this mechanism affects the absorption of nutrients, which is reflected in the growth and production of watermelon plants. For watermelon, $\mathrm{N}$ is one of the most required elements (Barros et al., 2012), but its excess causes the fruits to become less firm, waterier, and tasteless (Chitarra \& Chitarra, 2005).

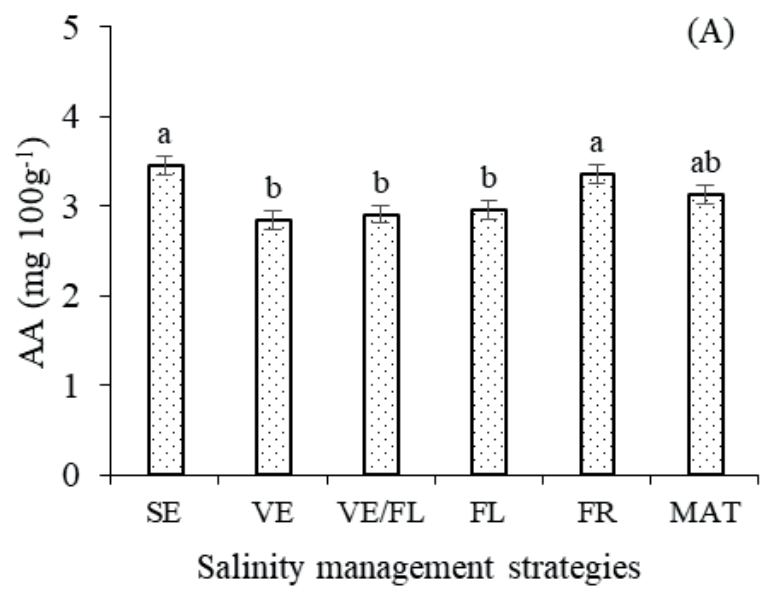

For the ascorbic acid contents (Figure 4A), plants cultivated under the SE and FR strategies showed statistically higher AA contents compared to those subjected to the $\mathrm{VE}, \mathrm{VE} / \mathrm{FL}$, and FL strategies. However, there was no significant difference between the AA contents of plants irrigated with saline water at the VE, VE/FL, FL, and MAT stages. The reduction in ascorbic acid content in watermelon fruits may be associated with a reduction in total soluble solids content, as vitamin $\mathrm{C}$ production is related to sugars present in the juice of the fruits, where in general the synthesis of AA occurs from hexose sugars (Taiz et al., 2017).

A. B. O. Sousa et al. (2016), in a study with the watermelon cv. 'Smile' irrigated using water with different salinity levels (ECw ranging from 1.0 to $5.0 \mathrm{dS} \mathrm{m}^{-1}$ ), also found that the ascorbic acid content of the fruits decreased with the salt stress imposed on the plants.

Figure 4. Contents of ascorbic acid AA (A) and total soluble solids TSS (B) of 'Sugar Baby' watermelon fruits as a function of management strategies of saline water use, at 85 days after sowing.

SE no stress throughout the crop cycle; VE salt stress only at the vegetative stage; VE/FL salt stress at the vegetative and flowering stages; FL salt stress at the flowering stage; FR salt stress at the fruiting stage; MAT salt stress at the fruit maturation stage.

Vertical bars represent the standard error of the mean $(n=5)$. Means with different letters indicate that treatments 
differ from each other by the Tukey test $(\mathrm{p}<0.05)$.

As observed for ascorbic acid contents (Figure 4A), total soluble solids were also affected by water salinity management strategies (Figure 4B). Watermelon fruits under the strategies SE, FL, FR, and MAT obtained the highest values of TSS (8.55, 8.58, 8.95, and $8.52{ }^{\circ}$ Brix), statistically differing from those subjected to salt stress at the vegetative and vegetative/flowering stages. Costa et al. (2013), when evaluating the production behavior and fruit quality of three watermelon cultivars ('Quetzali', 'Shadow' and 'Leopard') subjected to different levels of water salinity (ECw between 0.57 and 4.91 $\mathrm{dS} \mathrm{m} \mathrm{m}^{-1}$ ), observed that the increase in EC levels from 2.77 to $4.91 \mathrm{dS} \mathrm{m}^{-1}$ led to increments of 3.58 and $5.08 \%$ in the TSS values, respectively. According to these authors, such an increase is explained by the reduction of water absorption by the plant due to the decrease in the osmotic potential of the soil solution caused by excess salts.

It was also verified that the lowest contents of ascorbic acid (Figure 4A) were obtained when the plants were irrigated with saline water at the $\mathrm{VE}$, $\mathrm{VE} / \mathrm{FL}$, and FL stages. The lowest contents of total soluble solids (Figure 4B) in the fruits were observed in plants grown under VE and FL. It is worth pointing out that the level of sensitivity and/ or tolerance of crops to salt stress may vary between the development stages, but most crops, especially those of commercial importance, are more sensitive to salinity at the early phenological stages (Araújo et al., 2016).

According to the follow up of salinity management strategies within $\mathrm{N}$ doses for hydrogen potential (Figure 5A), it was observed that there was no significant difference between water salinity management strategies when $\mathrm{N}$ doses of 50 and $100 \%$ recommendation were used. However, the follow up of $\mathrm{N}$ doses within the SMS showed a significant effect of $\mathrm{pH}$ on plants irrigated under $\mathrm{SE}$ and VE/FL strategies. A higher $\mathrm{pH}$ in watermelon fruits can be attributed to the contents of organic acid, which normally decreases with maturation due to the conversion of sugars, besides the fact that some act as precursors of the Krebs cycle (Taiz et al., 2017) and undergo oxidative processes upon reaching full maturity. In addition, with maturation, the fruits rapidly lose acidity, but in some cases, there is a small increase in the values with the advance of maturation, thus justifying the increase in $\mathrm{pH}$ (Chitarra \& Chitarra, 2005).

When plants were cultivated under the VE/FL strategy (Figure 5A), the $\mathrm{N}$ dose of $100 \%$ favored the highest $\mathrm{pH}$ value of the watermelon fruits. However, watermelon plants fertilized with $50 \%$ of $\mathrm{N}$ and irrigated using water with low ECw (SE) obtained higher $\mathrm{pH}$ compared to those that received the highest $\mathrm{N}$ dose (100\% of the recommendation). Nitrogen fertilizers significantly increase soil salinity, to a point at which they negatively affect plant growth, due to physiological and metabolic changes (Han, Shi, Zeng, Xu, \& Wu, 2015), which may result in damage to the production and postharvest quality of watermelon fruits, such as a reduction in pulp $\mathrm{pH}$. In addition, $\mathrm{N}$ fertilization with urea may have acidified the substrate during the ammonia nitrification process, decreasing the availability of nutrients to plants due to the activity of $\mathrm{H}^{+}$(M. J. T. Dias, Souza, Natale, Modesto, \& Rozane, 2012). In addition, the salinity of some fertilizers, as in the case of urea, which has a salt index of 75, can reduce the osmotic potential, hampering the absorption of water and nutrients by plants, affecting their growth and, consequently, the production and postharvest quality of fruits.

For the anthocyanin contents of watermelon plants (Figure 5B), there was a significant difference between the SMS in plants fertilized with $50 \%$ of $\mathrm{N}$, with the highest ANT value found in those irrigated using water with low $\mathrm{ECw}$ along the cycle (SE), statistically differing from the other treatments (VE, VE/FL, FL, FR, and MAT). On the other hand, for plants fertilized with $100 \%$ of the $\mathrm{N}$ recommendation, the ANT contents were only higher under irrigation with low-salinity water (SE) and under $\mathrm{ECw}$ of $3.2 \mathrm{dS} \mathrm{m}^{-1}$ at the flowering stage. 
Changes in the postharvest quality of fruits in plants grown under salt stress conditions occur because of the negative effect of the osmotic potential of the soil solution; the excess of salts reduces the free energy of water and hampers the absorption of water and nutrients by plants, as well as their photosynthetic capacity, due to several factors, such as dehydration of cell membranes, reduction in $\mathrm{CO}_{2}$ supply, induced senescence

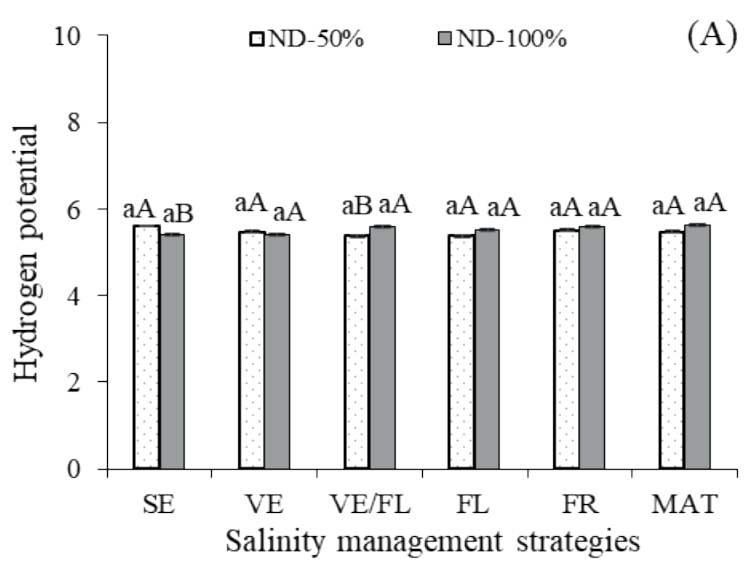

and change in enzymatic activity (Terceiro Neto, Gheyi, Medeiros, Dias, \& Campos, 2013). The alterations in these aspects may have contributed to the decrease in the anthocyanin contents of watermelon fruits. In addition, this pigment is sensitive to the $\mathrm{pH}$ conditions of the medium and may undergo degradation when exposed to these factors (Bordignon, Francescatto, Nienow, Calvete, \& Reginatto, 2009).

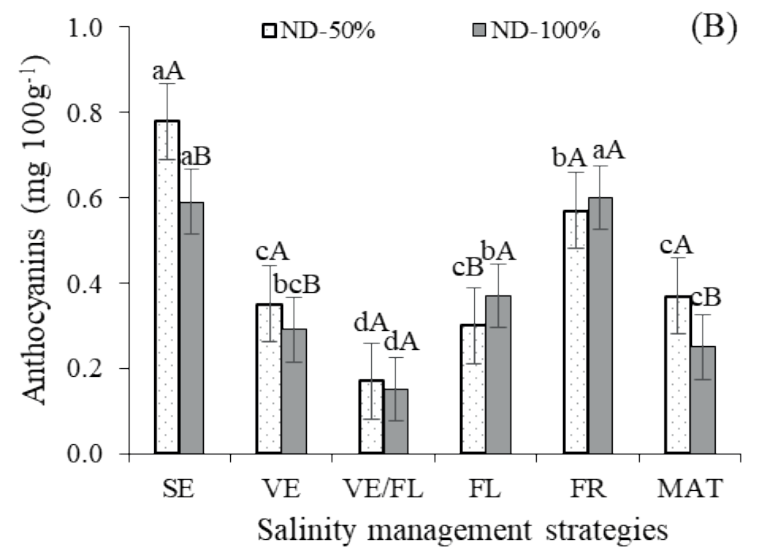

Figure 5. Follow up of the interaction between water salinity management strategies and nitrogen doses for hydrogen potential (A) and anthocyanins ANT (B) of "Sugar Baby" watermelon fruits, at 85 days after sowing. SE no stress throughout the crop cycle; VE salt stress only at the vegetative stage; VE/FL salt stress at the vegetative and flowering stages; FL salt stress at the flowering stage; FR salt stress at the fruiting stage; MAT salt stress at the fruit maturation stage.

Vertical bars represent the standard error of the mean $(n=5)$. Means with different letters indicate that treatments differ from each other by the Tukey test $(p<0.05)$.

Despite the reduction in the anthocyanin contents of fruits in plants grown under $\mathrm{N}$ dose of $50 \%$ of recommendation and subjected to the FR strategy in comparison to those irrigated using water with low $\mathrm{ECw}(\mathrm{SE})$, the anthocyanin contents in the fruits of these plants were higher than those of plants under the other management strategies. As this phenological stage (fruiting) directly influences the formation and postharvest quality of fruits, this can be an important aspect because anthocyanins perform several functions in plants, such as antioxidant functions, protection from the action of light, biological functions, and defense mechanisms (Bian, Yang, \& Liu, 2014; Canuto, Oliveira, Conceição, Farah, \& Tavares, 2016).

In the follow up of $\mathrm{N}$ doses within the SMS for anthocyanin contents (Figure 5B), differences were found in plants subjected to the SE, VE, FL, and MAT strategies. For the FL strategy, the N dose of $100 \%$ favored higher contents of ANT, while plants fertilized with $50 \%$ of $\mathrm{N}$ recommendation presented the lowest contents of ANT. On the other hand, for plants cultivated under SE, VE, and MAT strategies, the $\mathrm{N}$ dose of $50 \%$ of recommendation favored higher contents of ANT. As this recommendation of fertilization considers the weight of soil (Novais et 
al., 1991), i.e., it does not depend on the crop; the dose of $100 \mathrm{mg} \mathrm{kg}^{-1}$ of soil can be considered excessive for the watermelon crop. Moreover, the salt stress imposed on these plants may have contributed to the reduction in ANT content because the accumulation of total soluble salts in the soil compromises the growth of plants. After all, it reduces the osmotic potential of the soil solution, causing water stress, toxicity, and nutritional disorders in plants, besides affecting physiological processes and biochemical reactions. According to T. J. Dias, Cavalcante, Nunes, Freire and Nascimento (2012), the action of salts on plants, due to the increase in their concentration in the soil, contributes to the reduction of soil osmotic potential, specific ion toxicity, and imbalance in nutrient absorption by roots, causing the overall loss of fruit quality.

\section{Conclusion}

Salt stress applied at the vegetative and flowering stages reduces the contents of ascorbic acid and total soluble solids of 'Sugar Baby' watermelon fruits.

The dose of $50 \%$ of the $\mathrm{N}$ recommendation promotes a greater fresh weight of watermelon fruits.

Rind thickness and pulp thickness of 'Sugar Baby' watermelon fruits decreased with the salt stress applied at the vegetative and flowering stages and increased with $\mathrm{N}$ dose of $50 \%$.

The $\mathrm{N}$ dose of $100 \%$ promoted a greater increase in the $\mathrm{pH}$ of watermelon fruits at the vegetative and flowering stages.

The anthocyanin content of 'Sugar Baby' watermelon fruits decreases with salt stress, regardless of the development stage, and increases with the increase in the $\mathrm{N}$ dose of $50 \%$.

\section{Acknowledgments}

To the Coordination for the Improvement of Higher Education Personnel for granting a doctoral scholarship to the first author.

\section{References}

Araújo, E. B. G., Sá, F. V. da S., Oliveira, F. A. de, Souto, L. S., Paiva, E. P. de, Silva, M. K. do N., \& Brito, M. E. B. (2016). Crescimento inicial e tolerância de cultivares de meloeiro à salinidade da água. Revista Ambiente \& Água, 11(2), 462-471. doi: 10.4136/ ambi-agua. 1726

Ayers, R. S., \& Westcot, D. W. (1999). A qualidade da água na agricultura (2a ed.). (Irrigação e Drenagem, 29). Campina Grande: UFPB.

Barbosa, F. S., Lacerda, C. F., Gheyi, H. R., Farias, G. C., Silva Jr., R. J. C. , Lage, Y. A., \& Hernandez, F. F. F. (2012). Yield and ion content in maize irrigated with saline water in a continuous or alternating system. Ciência Rural, 42(10), 1731-1737. doi: 10.1590/ S0103-84782012001000003

Barros, M. M., Araújo, W. F., Neves, L. T. B. C., Campos, A. J. de, \& Tosin, J. M. (2012). Produção e qualidade da melancia submetida à adubação nitrogenada. Revista Brasileira de Engenharia Agrícola e Ambiental, 16(10), 1078-1084. doi: 10.1590/S141543662012001000007

Bian, Z. H., Yang, Q. C., \& Liu, W. K. (2014). Effects of light quality on the accumulation of phytochemicals in vegetables produced in controlled environments: a review. Journal of the Science of Food and Agriculture, 95(5), 869-877. doi: 10.1002/jsfa.6789

Bordignon Jr., C. L., Francescatto, V., Nienow, A. A., Calvete, E., \& Reginatto, F. H. (2009). Influência do $\mathrm{pH}$ da solução extrativa no teor de antocianinas em frutos de morango. Ciência e Tecnologia de Alimentos, 29(1), 183-188. doi: 10.1590/S010120612009000100028

Borgognone, D., Colla, G., Rouphael, Y., Cardarelli, M., Rea, E., \& Schwarz, D. (2013). Effect of nitrogen form and nutrient solution $\mathrm{pH}$ on growth and mineral composition of self-grafted and grafted tomatoes. Scientia Horticulturae, 149(1), 61-69. doi: 10.1016/j. scienta.2012.02.012

Canuto, G. A., Oliveira, D. R., Conceição, L. S. da, Farah, J. P., \& Tavares, M. F. (2016). Development and validation of a liquid chromatography method for anthocyanins in strawberry (Fragaria spp.) and complementary studies on stability, kinetics and antioxidant power. Food Chemistry, 192(1), 566574. doi: 10.1016/j.foodchem.2015.06.095

Chitarra, M. I. F., \& Chitarra, A. B. (2005). Pós colheita de frutas e hortaliças: fisiologia e manuseio (2a ed.). Lavras: UFLA. 
Costa, A. R. F. C. da, Medeiros, J. F. de, Porto, F. de Q., F ${ }^{\circ}$., Silva, J. S. da, Costa, F. G. B., \& Freitas, D. C. de. (2013). Produção e qualidade de melancia cultivada com água de diferentes salinidades e doses de nitrogênio. Revista Brasileira de Engenharia Agrícola e Ambiental, 17(9), 947-954, 2013. doi: 10.1590/ S1415-43662013000900006

Dias, M. J. T., Souza, H. A., Natale, W., Modesto, V. C., \& Rozane, D. E. (2012). Adubação com nitrogênio e potássio em mudas de goiabeira em viveiro comercial. Ciências Agrárias, 33(Supl. 1), 28372848. doi: 10.5433/1679-0359.2012v33Supl1p2837

Dias, T. J., Cavalcante, L. F., Nunes, J. C., Freire, J. L. de O., \& Nascimento, J. A. M. (2012). Qualidade física e produção do maracujá amarelo em solo com biofertilizante irrigado com águas salinas. Semina: Ciências Agrárias, 33(Supl. 1), 2905-2918. doi: 10.5433/1679-0359.2012v33Supl1p2905

Donagema, G. K., Campos, D. V. B. de, Calderano, S. B., Teixeira, W. G., \& Viana, J. H. M. (2011). (Orgs.), Manual de métodos de análise de solo (2a ed.). Rio de Janeiro, RJ: EMBRAPA Solos.

Fageria, N. K., Gheyi, H. R., \& Moreira, A. (2011). Nutrient bioavailability in salt affected soils. Journal of Plant Nutrition, 34(7), 945-962. doi: 10.1080/01904167.2011.555578

Ferreira, D. F. (2014). Sisvar: a guide for its bootstrap procedures in multiple comparisons. Ciência $e$ Agrotecnologia, 38(2), 109-112. doi: 10.1590/ S1413-70542014000200001

Francis, F. J. (1982). Analysis of anthocyanins. In P. Markakis (Ed.), Anthocyanins as food colors (pp. 181-207). New York: Academic Press.

Guedes, R. A. A., Oliveira, F. A., Alves, R. C., Medeiros, A. S., Gomes, L. P., \& Costa, L. P. (2015). Estratégias de irrigação com água salina no tomateiro cereja em ambiente protegido. Revista Brasileira de Engenharia Agrícola e Ambiental, 19(10), 913-919. doi: 10.1590/1807-1929/agriambi.v19n10p913-919

Gupta, B., \& Huang, B. (2014). Mechanism of salinity tolerance in plants: physiological, biochemical, and molecular characterization. International Journal of Genomics, 2014(1), 1-18. doi: 10.1155/2014/701 596

Han, J., Shi, J., Zeng, L., Xu, J., \& Wu, L. (2015). Effects of nitrogen fertilization on the acidity and salinity of greenhouse soils. Environmental Science and Pollution Research, 22(4), 2976-2986. doi: 10.1007/ s11356-014-3542-z
Instituto Adolfo Lutz (2008). Métodos físico-químicos para análises de alimentos (4a ed.). São Paulo: Instituto Adolfo Lutz.

Instituto Brasileiro de Geografia e Estatística (2017). Produção agrícola municipal. Recuperado de https:// sidra.ibge.gov.br/pesquisa/pam/tabelas

Lacerda, C. F., Neves, A. L. R., Guimarães, F. V. A., Silva, F. L. B. da, Prisco, J. T., \& Gheyi, H. R. (2009). Eficiência de utilização de água e nutrientes em plantas de feijão-de-corda irrigadas com água salina em diferentes estádios de desenvolvimento. Engenharia Agrícola, 29(02), 221-230. doi: 10.1590/ S0100-69162009000200005

Lacerda, C. F., Silva, F. B., Neves, A. L. R., Silva, F. L. B., Gheyi, H. R., Ness, R. L. L., \& Gomes, E., $\mathrm{F}^{\mathrm{o}}$. (2011). Influence of plant spacing and irrigation water quality on a cowpea-maize cropping system. International Research Journal of Agricultural Science and Soil Science, 1(5), 163-167.

Lopes, Á. L. de O., Rocha, D. R., Gonçalves, I. C. R., Cunha, C. S. M., \& Silva, A. F. R. (2016). Resposta agronômica à aplicação de doses de nitrogênio e a modos de disponibilização de micronutrientes na melancia. Agropecuária Científica no Semiárido, 12(2), 199-210. doi: 10.30969/acsa.v12i2.753

Melo, E. N. de, Nobre, R. G., Pinheiro, F. W. A., Souza, L. de P., Lima, G. S. de, Gheyi, H. R.,... Silva, W. L. da. (2018). Evaluation of West Indian cherry (Malpighia emarginata) rootstock under saline water irrigation and nitrogen fertilization. Australian Journal of Crop Science, 12(06), 1034-1040. doi: 10. 21475/ajcs.18.12.06.PNE1314

Novais, R. F., Neves, J. C. L., \& Barros, N. F. (1991). Ensaio em ambiente controlado. In A. J. Oliveira (Ed.), Métodos de pesquisa em fertilidade do solo (pp. 189-253). Brasília: EMBRAPA-SEA.

Oliveira, L. A. de, Korndorfer, G. H., \& Pereira, A. C. (2007). Acumulação de silício em arroz em diferentes condições de $\mathrm{pH}$ da rizosfera. Revista Brasileira de Ciência do Solo, 31(4), 685-690. doi: 10.1590/S0 100-06832007000400009

Richards, L. A. (1954). Diagnosis and improvement of saline and alkali soils. (USDA, Agriculture Handbook, 60). Washington: U. S. Department of Agriculture.

Silva, A. F. (2016). Eficiência fotossintética e proteção oxidativa em mudas de cajueiro anão precoce submetidas ao estresse salino. Dissertação de mestrado, Universidade Estadual da Paraíba, Campina Grande, Brasil. 
Sousa, A. B. O. de, Duarte, S. N., Sousa, O. N. D. de, Neto, Souza, A. C. M., Sampaio, P. R. F., \& Dias, C. T. dos S. (2016). Production and quality of mini watermelon cv. Smile irrigated with saline water. Revista Brasileira de Engenharia Agrícola e Ambiental, 20(10), 897-902. doi: 10.1590/18071929/ agriambi.v20n10p897-902

Sousa, V. F. de, Coelho, E. F., Souza, V. A. B. de, \& Holanda, R. S. F. de, Fo . (2005). Efeitos de doses de nitrogênio e potássio aplicadas por fertirrigação no meloeiro. Revista Brasileira de Engenharia Agrícola e Ambiental, 9(2), 210-214. doi: 10.1590/S141543662005000200010

Souza, L. de P., Nobre, R. G., Silva, E. M., Sousa, F. F., \& Silva, I. A. (2015). Desenvolvimento de porta-enxerto de goiabeira sob irrigação com água salinizadas e doses de nitrogênio. Revista Verde de Agroecologia e Desenvolvimento Sustentável, 10(2), 176-182. doi: 10.18378/rvads.v10i2.3717

Su, S., Zhou, Y., Qin, J. G., Wang, W., Yao, W., \& Song, L. (2012). Physiological responses of Egeria densa to high ammonium concentration and nitrogen deficiency. Chemosphere, 86(5), 538-545. doi: 10.1016/j. chemosphere.2011.10.036
Taiz, L., Zeiger, E., Møller, I. M., \& Murphy, A. (2017). Fisiologia vegetal. Porto Alegre: Artmed Editora.

Terceiro Neto, C. P. C., Neto, Gheyi, H. R., Medeiros, J. F. de, Dias, N. da S., \& Campos, M. de S. (2013). Produtividade e qualidade de melão sob manejo com água de salinidade crescente. Pesquisa Agropecuária Tropical, 43(4), 354-362. doi: 10.1590/S198340632013000400007

Torres, E. C. M., Freire, J. L. O., Oliveira, J. L., Bandeira, L. B., Melo, D. A., \& Silva, A. L. (2014). Biometria de mudas de cajueiro anão irrigadas com águas salinas e uso de atenuadores do estresse salino. Nativa, 2(2), 71-78. doi: 10.14583/2318-7670.v02n02a03

Wang, C., Zhang, H. S., Wang, P. F., Li, W., \& Lu, J. (2010). Effects of ammonium on the anti oxidative response in Hydrilla verticillata (L.f.) Royle plants. Ecotoxicology and Environmental Safety, 73(2), 189-195. doi: 10.1016/j.ecoenv.2009.08.012

Wong, M. (2005). Visual symptoms of plant nutrient deficiencies in nursery and landscape plants. Soil and Crop Management, 1(1), 1-4. 
